\title{
IMPACT OF PSYCHOLOGICAL EMPOWERMENT ON THE PERFORMANCE OF EMPLOYEES IN THE FOUR- AND FIVE-STAR HOTEL SECTOR IN THE DEAD SEA-JORDAN TOURIST AREA
}

\author{
Issam Mohammad AL-MAKHADMAH* \\ Al-Balqa Applied University, Tourism Management Department, Ajloun College, Jordan, e-mail: isammakhadmeh@bau.edu.jo \\ Bashar M. AL NAJDAWI \\ Al-Balqa Applied University, Aqaba University College, Aqaba City, \\ Jordan - Head of Hotel Management \& Tourism Science Department, e-mail: najdawi@bau.edu.jo \\ Imad Mohmad AL-MUALA \\ Amman Arab University, Business Administration Department, Faculty of Business, Amman, Jordan, e-mail: almuala@aau.edu.jo
}

\begin{abstract}
Citation: Al-Makhadmah, I.M., Al Najdawi, B.M., \& Al-Muala, I.M. (2020). IMPACT OF PSYCHOLOGICAL EMPOWERMENT ON THE PERFORMANCE OF EMPLOYEES IN THE FOUR- AND FIVE-STAR HOTEL SECTOR IN THE DEAD SEA-JORDAN TOURIST AREA. GeoJournal of Tourism and Geosites, 30(2spl), 896-904. https://doi.org/10.30892/gtg.302spl16-520
\end{abstract}

\begin{abstract}
This study aims to identify the influence of psychological empowerment dimensions (i.e., meaning, impact, competence, and selfdetermination) on employee performance. The current research also intends to explore whether the educational level of employees affects the relationship between psychology empowerment and their performance in hotels. This study uses exploratory analysis questionnaire developed from previous studies. Sample $(n=200)$ was selected from employees in four- and five-star hotels in the Dead Sea tourism area. Results indicate that meaning and self-determination have an impact on the performance of employees, whereas impact and competence have no effect on their performance. In addition, education level significantly moderates the relationship between impact and employee performance but did not modify the relationship among meaning, competence, and self-determination. This study believes that focus should be provided to considerably empower hotel employees to achieve the hotel goals. Lastly, the current research enriches the knowledge base of specialized departments and researchers specializing in the performance of employees in service organizations and hotels in Jordan.
\end{abstract}

Key words: Psychology Empowerment, Performance, Hotel Sector, Dead Sea

$* * * * * *$

\section{INTRODUCTION}

Organizations currently face successive circumstances and rapid changes in the light of internal and external influences, the most important of which are the technological developments and globalization of operations and markets (Tetik, 2016). Apart from increasing the aspirations and expectations of employees, the needs and expectations of customers have increased the competition among organizations. These challenges are considered constant in testing the abilities of senior management to adapt to these conditions and situations, thereby requiring a search for new methods to cope with these developments (Yukl and Becker, 2006). The face of these challenges takes many forms, the most important of which are attention to human resources and creation of an appropriate working environment for individuals, which is considered one of the main factors in the labor-intensive organizations (Bhatnagar, 2005).

Organizations are aware that employees are their most important financial sources (Hanaysha and Tahir, 2016; Al Najdawi, 2020). No one can deny that the hotel sector needs an extensive human element and to constantly provide jobs for employees of numerous departments within hotels (Patah et al., 2009; Mohammad et al., 2014). The success of a hotel depends on the manner that customers are served because employees' behavior and performance substantially affects the former's perception of the service provided (Kara et al., 2013; Al Najdawi et al., 2017). The management and development of human resources is the cornerstone of the majority of hotel organizations; hence, this sector aims to strengthen organizational capabilities by attracting and accrediting the necessary competencies capable of keeping abreast of current and future challenges and ensuring their continuity in the market (Kassawnh et al., 2019; Jawabreh et al., 2020). Therefore, human resources can be defined as the optimal use of the human element available and expected in organizations (Abazeed, 2010). Hotel organizations seek to adopt the foundations and strategies that facilitate the maximization of every individual working within hotels. These elements include employment, training, evaluation, and other aspects related to the human element (Durrah et al., 2014).

The importance of empowering employees from the relatively new interests of management scientists is a result of the development of new concepts of work and performance, as well as the adoption of advanced standards to evaluate successes and failures. These standards adopt quality and perfection, and strive to achieve excellence within the hotel establishment (Jaradat et al., 2013). Empowerment is achieved by meeting hotel objectives through the involvement of its employees. Moreover, hotel organizations need the information, knowledge, skill, and expertise of employees to achieve their goals (Jaradat et al., 2013). Evidently, an administrative environment should be created to shift from a traditional hierarchical style to one that is consistent with changes that ensure employee empowerment and solidify citizenship, belongingness, and allegiance (Shelton, 2002). Employee empowerment should also be used as a competitive tool to allow them to immediately make the right decision without permanent reference to higher departments. Accordingly, this notion can help employees utilize their creativity, reduce expenses, and create efficient and cost-effective mechanisms (Al-douri, 2018). Hence, empowerment is an administrative technique to enable working individuals become solely responsible for their good job performance.

The psychological empowerment of working individuals is a relatively recent subject, and complements previous studies on management science and management of human resources in organizations, particularly in service organizations (e.g., hotels). However, many studies on empowerment and related issues have failed to address the link between psychological empowerment and employee performance in Jordan's hotel sector. In addition, psychological empowerment is one of the indicators of effective hotel employee performance because of its role in 
the success of hotels and improvement of employee performance efficiency, as well as in incentives, training, and internal marketing. The current study is based on a vital issue of hotels, particularly in terms of providing distinguished services to customers. This research is also related to the improvement and development of human resources and the hotel sector's role as important and largest provider of employment opportunities in Jordan. In light of the tourism development, hotels should constantly improve their performance through employee performance to ensure their sustainability in the tourism market and achieve their profitability goals. Psychological empowerment and its procedures and components are important tools for improving employee performance and achieving the hotel objectives. Psychological empowerment is also an indicator of the importance of individuals as a key element in successfully providing hotel services (Ibrahim, 2020). Only a few studies have been conducted on the impact of psychological empowerment in achieving and developing employee performance. Field studies on the impact of psychological empowerment on Jordanian hotel employees are also lacking.

The purpose of current study is to examine the effects of psychological empowerment elements (i.e., meaning, impact, competence, and self-determination) on employee performance in the hotel sector. Moreover, this research intends to evaluate the moderating effects of educational level on the relationship between psychological empowerment elements and employee performance. This study aims to achi eve the following key objectives:

- To measure the relationship between the elements of psychological empowerment (i.e., meaning, impact, competence, selfdetermination) and performance of employees in four- and five-star hotels in the Dead Sea tourist destination;

- To explore whether the education level of these employees affects the relationship between psychological empowerment and their performance;

- To develop a set of recommendations to enhance the psychological empowerment of hotel employees, this will positively reflect their performance.

\section{LITERATURE REVIEW}

\section{Psychological Empowerment}

Empowerment has been discussed in many human and administrative fields (Saif and Saleh, 2013), and human resource strategies to achieve the best from staff (Sandhya and Sulphey, 2020). The idea of empowering involves senior management delegating authority and decision-making to the organization's employees (Durrah et al., 2014; Ibrahim, 2020). Conger and Kanungo (1988) defined employee empowerment "as a process of enhancing feelings of self-efficacy among organizational members." In recent decades, empowerment has been studied and discussed through two main approaches. The organizational approach focuses on the delegation of powers and granting of authority from the higher administrative levels to the lower levels. Psychological empowerment is another approach that focus es on the mental state of working individuals. Psychological empowerment reflects individuals' attitudes toward their functions in the work place. Both approaches play an important role in the development of theory of empowerment (Conger and Kanungo, 1988; Thomas and Velthouse, 1990; Spreitzer, 1995; Cunningham et al., 1996; Erstad, 1997; Field, 1997; Appelbaum et al., 1999; Eylon and Bamberger, 2000; Chang and Liu, 2008; Khan et al., 2020). Psychological empowerment is particularly important for organizations because of its potential for positive workplace outcomes, which serve as the general goals of organizations (Tetik, 2016). Studies have also focused on employee satisfaction and its relationship to employee performance (Sun, 2016). Many studies have defined psychosocial empowerment and its components and provided precise description this concept and its related procedures and elements. Bandura (1986) believed that empowerment is a selfsustaining construct. Conger and Kanungo (1988) defined psychological empowerment as an internal motivation that reflects individuals' awareness of their actions and roles, which revolve around meaning, ability, autonomy, and influence. Spreitzer (1995) defined psychological empowerment as a set of motivational cognitions shaped by the work environment and reflects individuals' active orientation to their respective work roles. Thus, the researchers conclude that the concept of psychological empowerment is a condition of individuals' sense of importance within the work environment, which is positively reflected on their performance.

The psychological empowerment of individuals is one of the most appropriate topics and fields in the hospitality industry, and provides positive results to employee performance and customer service management processes (McGrath, 2007). Psychological empowerment is also suitable for high-value, highly interactive individuals and clients, such as hotels (Bowen and Lawler, 1995; Cacioppe, 1998). Moreover, psychological empowerment in the hospitality industry is considered a management gesture to involve employees in decision-making, authority, and responsibilities during interaction with customers, thereby providing impetus to focus on this field (Klidas, 2002). The importance of employee empowerment has been highlighted to improve the competitive advantage of hotels and the quality of their services (Hubrecht and Teare, 1993; Lashley and McGoldrick, 1994; Ponton, 2011). Moreover, individuals often need to feel that they are capable of doing their jobs positively and that they are effective in the work environment (Fineman, 2009; Khan et al., 2020). This notion is reflected in the commitment and professionalism in providing services to clients (Barbee and Bott, 1991; Van Oudtshoorn and Thomas, 1995). Psychological empowerment is also important in producing positive behavioral outcomes in the work environment. Individuals with a high sense of self-confidence are able to handle customer requests, effectively solve current problems, provide an ideal service (Lashley, 1996; Khan et al., 2011; Tetik, 2016), and manifest willingness to find the best ways and alternatives to perform their work (Tetik, 2016; Pathak and Srivastava, 2020). It also encourages individuals to create an environment for selfdevelopment goals in the work environment (Al-douri, 2018). Chebat and Collias (2000) believed that empowerment stimulates individuals' desire to change their behavior toward clients to achieve individual and organization goals. Psychological empowerment contributes to increased individual effectiveness and customer satisfaction, there by resulting in satisfaction and deepened commitment and loyalty to organizations (Chow et al., 2006). Empowered individuals are fully prepared and responsible in the workplace, and their response to the needs of clients is immediate and professional (Barbee and Bott, 1991). Evidently, psychological empowerment in hotel organizations is a basic requirement to motivate employees to perform their duties in the desired manner. Accordingly, the re sults of such a performance are positively reflected on the employees themselves, clients, and the organization.

Meaning: Meaningful is "a sense of purpose or personal connection to one's work goals" (Spreitzer, 1995; Ibrahim, 2020). The staff supposes that their occupation or job has value (Saif and Saleh, 2013). This notion means that employees believe that their respective personalities are worthwhile (Ambad and Bahron, 2012), and related to their focus and effort in the workplace (Thomas and Velthouse, 1990). Wang and Lee (2009) explained that the meaning appears clearly when compatibility exists between the staff and their workplace and the value of goals and tasks (Thomas and Velthouse, 1990). Moreover, connection to work will be strong and positive and loyalty to hotels will be enhanced when individuals recognize a comfortable work environment, amiable teamwork, and competitive salary and incentives (Zhu et al., 2012). Al-douri (2018) believed that the meaning is related to task performance and its value to the staff. Many studies have demonstrated the strong relationship between meaning (as a component of psychological empowerment) and employee 
performance (Spreitzer, 1995). Hackman and Oldham (1976) explained that meaning has a positive and powerful effect on performing tasks in the work environment.

Finally, this study indicated that the meaning is a sense of the importance of employees' tasks and duties as an integral component of the services provided to customers.

Impact: Impact is related to the ability of individuals to make a difference in their organization, achieve work goals, such as high performance (Saif and Saleh, 2013), improve organization strategy and management operations, and produce positive outcomes (Ashforth, 1989; Spreitzer, 1995) stated that employee can influence the organizational system where they belong. Moreover, impact relates to the degree of individuals' belief that their behavior can achieve organization goals (Zhang and Barto, 2010) and create a positive work environment (Bester et al., 2015). The presence of this dimension would make individuals be diligent in performing their tasks, thereby reflecting positively in the organization (Choong et al., 2011; Safari et al., 2020). Impact also refers to employees' strength of personality in the work environment (Johnson, 2009) and the use of their abilities and skills to meet the challenges of the professional and organizati onal working environment (Saif and Saleh, 2013). Furthermore, individuals recognize the importance of influencing the work, duties, and responsibilities required to achieve performance requirements, thereby preparing them to consistently improve their performance (Choong et al., 2011). Bedarkar and Pandita (2014) emphasized that the impact of individuals refers to the power to make decisions and to use skills, knowledge, and self-confidence. These factors contribute to the provision of appropriate solutions and suggestions for the achievement of the objectives shared by senior management and employees (Spreitzer, 1995). Ashforth (1990), Ambad and Bahroon (2012), and Li et al. (2014) determined the importance of impact on employee performance. Evidently, impact has an effect in the employees' knowledge, skills, and overall work performance. Accordingly, impact can be maximized to provide employees with an improved work environment.

Competence: Competence is known as the perception of individual ability to implement tasks and duties professionally based on knowledge, experiences, and skills (Jaradat et al., 2013; Turnipseed and VandeWaa, 2020), as well as the capability to efficiently perform task (Zhang and Barto, 2010). Al-douri (2018) and Johnson (2009) explained that competence is the ability to face challenges in the internal and external environment by creating an environment conducive for thinking, creativity, and training employees in decision-making, initiative, and innovation (Spreitzer, 1995; Ibrahim, 2020). Thomas and Velthouse (1990) stated that competence is the individual confidence and ability to competently engage in activities within the workplace. Bandura (1977) believed that self-efficacy is derived from competence. The sense of efficiency can be enhanced through effective supervision, which is determined by feedback on performance and creative motivation of employees (Spreitzer, 1995). In addition, efficiency plays an important role in the motivation and positive continuation of performance through mental effort during work and achieving goals with high efficiency (Zimmerman, 2000). Competence also enhances the sense of efficiency in dealing with difficult tasks and individuals' belief in their ability to succeed in the tasks entrusted to them (Yakin and Erdil, 2012). However, low-skilled employees tend to avoid confronting their fears and developing their abilities (Choong et al., 2011). Moreover, individuals who lack confidence in their skills and ability will not feel empowered by their supervisors (Yakin and Erdil, 2012). Several studies have confirmed that competence is crucial in developing and improving the performance of individual organizations (Bandura, 1986; Ahearne et al., 2005).

Self-determination: Self-determination relates to individual belief in control and independence in performing tasks (Zhang and Barto, 2010; Khan et al., 2020). Hrbackova and Sunchankova (2016) defined self-determination as opportunities for employees to express ideas and suggestions and to feel successful through the powers and responsibilities given to them by senior management. Autonomy in the workplace indicates the ability of individuals to overcome problems at all levels and tasks related to the work place and performance (Gözükara and Şimşek, 2015). Autonomy also presents the choice of modality to implement the workplace duties (Choong et al., 2015). Moreover, when individuals feel that they have relative freedom and independence in performing their tasks and duties, they will make correct decisions and accomplish tasks in a professional manner (Hossein et al., 2012; Saif and Saleh, 2013). Self-esteem is shown when individuals have certain control over what they do and when they can express their opinion on performing their duties profes sionally. That is, people will not consider to be under their bosses and are doing merely what they want (Ibrahim, 2020). They will not feel empowered because of the lack of autonomy and freedom (Choong et al., 2011; Al-douri, 2018).

Several studies have shown the importance of self-determination and its impact on performance. These studies have agreed that selfdetermination and a sense of independence at work lead to individuals' self-confidence and reflect on their behavior when performing their tasks and duties (Miller and Mong, 1986; Stajkovic and Luthane, 1998; Liden et al., 2000; Ambad and Bahroon, 2012).

\section{Performance}

Employee performance is defined as activities and tasks that are effectively and efficiently performed by individuals (Saleem et al., 2018). Moreover, employee behavior is linked to the goals of the organization (Campbell, 1993), and deemed by operational and financial performance (Sarwar and Muhammad, 2020). Performance is an important indicator of how tasks and duties are performed and the problems faced by individuals in the work environment (Rothmann and Coetzer, 2003). Chow et al., (2006) determined that empowerment contributes to supporting the performance of employees in food supply companies.

Bartram and Casimir (2007) confirmed that the performance of staff, which is associated with supervisors, has an impact on the granting of psychosocial empowerment. Tuuli and Rowlinson (2009) determined a direct and positive impact on employee performance. Koberg et al., (1999) indicated that psychological empowerment affects the productivity and effectiveness of employees at work. Mir and Rainayee (2015) noted that psychological empowerment directly and indirectly affects employee performance through job satisfaction Zhang and Bartol (2010) and Singh and Sarker (2012) noted that psychological empowerment affects individual productivity, improves individuals' ability to acquire knowledge and skills, and improves their work performance (Siachou and Gkorezis, 2014). Geralis and Terziovski (2003) studied Australian banks and determined that the practice of applying the elements of psychological empowerment with the performance of employees in the hotel sector. Baird et al. (2018) discussed that empowerment increases employees' sense of responsibility, improves productivity, and contributes to improved results for the organization. Lee and Koh (2001) found that employee performance within the hotel organization has a positive or negative effect. The more people are able to work, the more positive the performance of individuals and their responsibilities toward the hotel organization and the staff. By contrast, the more poorly the employees perform, the lower their level of performance and the lower the customers' satisfaction will be. Numerous studies have focused on the importance of the relationship between psychological empowerment and employee performance in organizations (Spreitzer, 1995; Kirkman et al., 2004; Aryee and Chen, 2006; Bartram and Casimir, 2007; Chiang and Hsieh, 2012; Fong and Snape, 2015; Kundu et al., 2019). 


\section{STUDY HYPOTHESES}

The current study uses the literature review as basis to formulate the following hypotheses:

H1: Meaning has a significant effect on employee performance.

H2: Impact has a significant effect on employee performance.

H3: Competence has a significant effect on employee performance.

H4: Self-determination has a significant effect on employee performance.

H5: Education level significantly moderates the relationship between meaning and performance.

H6: Education level significantly moderates the relationship between impact and performance.

H7: Education level significantly moderates the relationship between competence and performance.

H8: Education level significantly moderates the relationship between self-determination and performance.

The following framework describe the relations between factors (Figure 1).

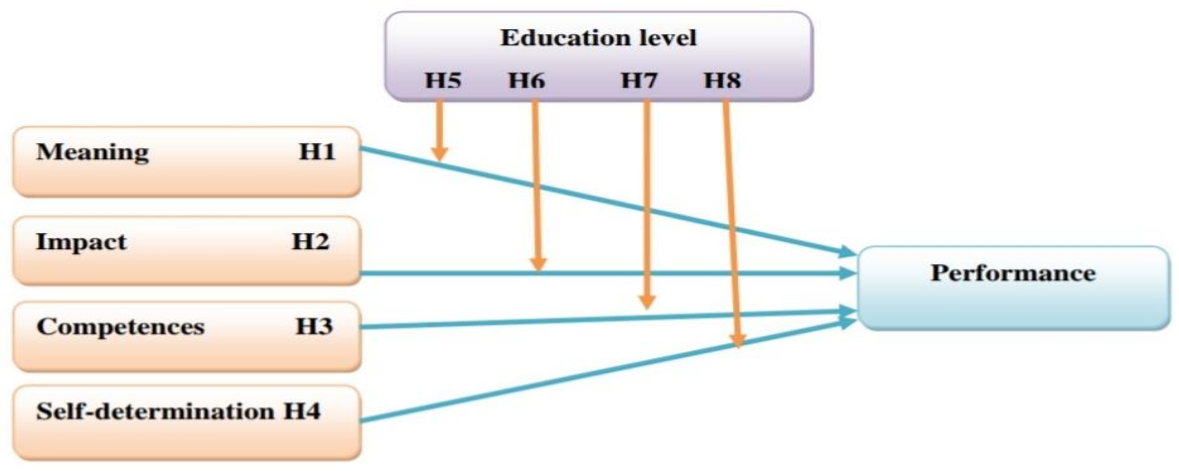

Figure 1. Study framework

\section{METHODOLOGY}

\section{Sample}

From the statistics of Ministry of Tourism and Antiquities of Jordan, The primary data in this study were collected from nine four- and five-star hotels in the Dead Sea tourism area. In particular, room division represents the target population of (6) five-star hotels and (3) fourstar hotels. Process of data collection was carried out based on the needs to analyze the research problem. All hotels agreed to participate in this research through human resources managers' acceptance. The procedures of data collection involved an arrangement with the hotels human resource managers to collect the data in two stages: first; with the shift an employee which started daily from 8.00 AM to 4.00 PM. Second; shift B which started at 4.00 PM to 12.00 AM. Also, the data collected by researchers. Every researcher was focusing on one hotel to complete collecting the data required and after finishing that the researcher Trans to another hotel.

A total of 200 questionnaires were distributed randomly to the room division employees. A total of 25 questionnaires were dis tributed to the room division staff in each five-star hotel, 17 questionnaires in 2 four-star hotels, and 16 questionnaires in one four-star hotel. A total of 192 questionnaires were returned and 8 questionnaires were excluded for lack of validity for the analysis. The number of questionable questionnaires was 184, which was the basis of this study to obtain the results. This study used the statistical analysis method (SPSS). The researchers considered the time, stress, and responsibilities of the participants. To avoid these difficulties, the following steps were considered. First, the researchers requested permission from the human resource managers of the hotels of the target population to conduct research. Second, the confidentiality of the responses was assured to obtain realistic, honest, and candid responses. Third, the data were collected personally by the researchers to achieve high-level responses. Primary data was collected over duration of one week from 5 to 11 January 2019, this period represented low hotel occupancy during low season, which helped researchers to collect the data easily.

\section{Measures}

The main source of this research is a questionnaire developed by the researchers from previous studies. The questionnaire is related to the system that uses a five-point Likert scale, which ranges from strongly disagree (1) to strongly agree (5). The instrument is divided into three sections. The first section includes the background or demographic questions to assess the participant characteristics. The second section focuses on psychological empowerment and its components. A total of (24) items were adopted from previous studies: six items investigated meaning from Onyemeh (2017), five items and one item from Jaradat et al., (2013), impact with six items were developed by Onyemeh (2017) four items, and two items by Jaradatet et al. (2013). Competences measured by Six items were derived from Onyemeh (2017) five items, and one item from Jaradat et al. (2013). Six items measured self-determination adopted by Onyemeh (2017) five items, and one item from Jaradat et al. (2013). The third section includes seven items developed by Al-douri (2018) to assess the performance of hotel employees.

\section{RESULTS}

The results display that the percentage of males reached $75.0 \%$, while that of females reached $25.0 \%$. This result indicates the researchers' interest in obtaining data and taking the opinions of both genders. The majority of the respondents are in the age 20-29 age group (60.9\%). Forth educational level, the majority of the respondents hold a bachelor's degree $(38.6 \%)$, followed by diploma (28.8\%), high school graduates $(26.6 \%)$, and graduate degrees $(6.0 \%)$. Several respondents $(37.5 \%)$ have below5 years of experience in hospitality work (Table 1$)$.

\section{Reliability}

Table 2 shows that Cronbach's alpha of the study tools is above 0.60 , thereby indicating the consistency between the study tool paragraphs.

\section{HYPOTHESIS TESTING}

To test the hypotheses, regression analysis was conducted on the psychological empowerment cognitions: meaning (H1), impact (H2), competence (H3), and self-determination (H4); and employee performance. Table 3 presents the results. 
Table 1. Demographics of the respondents

\begin{tabular}{|c|c|c|c|}
\hline & Percent & Frequency & Category \\
\hline \multirow{3}{*}{ Age } & $20-29$ & 112 & 60.9 \\
\cline { 2 - 4 } & $30-39$ & 49 & 26.6 \\
\cline { 2 - 4 } & $40-49$ & 23 & 12.5 \\
\hline Total & & 184 & $100 \%$ \\
\hline \multirow{2}{*}{ Gender } & Male & 138 & 25.0 \\
\hline Total & Female & 46 & $100 \%$ \\
\hline \multirow{3}{*}{ Education level } & & 184 & 26.6 \\
\cline { 2 - 4 } & High School & 49 & 28.8 \\
\cline { 2 - 4 } & Diploma & 53 & 38.6 \\
\cline { 2 - 4 } & Bachelor & 71 & 6.0 \\
\hline Total & Graduate & 11 & $100 \%$ \\
\hline \multirow{3}{*}{ Experience } & & 184 & 37.5 \\
\cline { 2 - 4 } & Less of 5 & 69 & 30.4 \\
\cline { 2 - 4 } & $6-10$ & 56 & 6.5 \\
\cline { 2 - 4 } & $11-15$ & 40 & 3.8 \\
\cline { 2 - 4 } & $16-20$ & 12 & $100 \%$ \\
\hline Total & $21 \%$ above & 184 & \\
\hline
\end{tabular}

Table 2. Cronbach's Alpha Measures

\begin{tabular}{|c|c|c|}
\hline Dimension & Cronbach's Alpha & N of Items \\
\hline Meaning & .767 & 6 \\
\hline Impact & .775 & 6 \\
\hline Competences & .730 & 6 \\
\hline Determination & .725 & 7 \\
\hline Performance & .811 & 6 \\
\hline
\end{tabular}

Table 3. Regression Analysis

\begin{tabular}{|l|c|c|c|c|c|}
\hline \multicolumn{7}{|c|}{ Coefficients } \\
\hline & Std. Error & Beta & T & Sig & R square \\
\hline (Constant) & 2.344 & & 10.06 & .020 & .512 \\
\hline Meaning & 4.613 & .280 & 2.344 & .000 & \\
\hline Impact & 1.766 & .116 & 4.613 & .079 & \\
\hline Competences & $1.070-$ & $.063-$ & 1.766 & .286 & \\
\hline Determination & 7.567 & .495 & $1.070-$ & .000 & \\
\hline Dependent Variable: Employee Performance \\
\hline
\end{tabular}

The result indicates that the overall psychology empowerment explains $51 \%$ of variance in employee performance.

H1: Meaning has a significant effect on employee performance.

The result demonstrates that meaning is statistically positive and significantly contributes to the prediction of employee performance $(B=$ $.28 ; \mathrm{p}<.05)$. Thus, $\mathrm{H} 1$ is supported. This means that an employee who believes in his job and has value, will exert more effort in workplace.

H2: Impact has a significant effect on employee performance.

The result shows that impact is positive, but fails to provide significant contribution to the prediction of employee performance $(ß=.116$; $\mathrm{p}=.079$ ). Hence, $\mathrm{H} 2$ is not supported. This means that employees didn't make different in work hotels goals and impact didn't relate to their performance

H3: Competence has a significant effect on employee performance.

The result shows that competence fails to provide significant contribution to the prediction of employee performance $(\beta=.063 ; \mathrm{p}=.286)$. Thus, H3 is not supported. Which means that the employee's competences didn't link to performance of hotel at all from their view of point

H4: Self-determination has a significant effect on employee performance.

The result demonstrates that the Self-determination is statistically positive and significantly contributes to the prediction of employee performance $(\beta=.495 ; \mathrm{p}<.05)$. Hence, H4 is supported. Which means more employee Self-determination more likely performance.

Interacting Effects of Education Level and Impact on Employee Performance in Jordanian Hotels

To measure whether educational level significantly moderates the relationship between psychological empowerment and performance, the moderator variable was included with the independent variables in Step 2, the moderator variable also explains approx imately 53\% of the employee performance variance. Impact is not significantly related to employee performance. The interaction terms were includ ed in Step 3, and an increase in $\mathrm{R} 2$ by $1.2 \%$ is noted. Table 4 and shows the results of the hierarchical multiple regression analysis.

H5: Education level significantly moderates the relationship between meaning and performance

The result shows that the educational level fails to moderate the effect of meaning on employee performance $(\beta=.427-; p=.350)$. Thus, H5 is not supported. This means the educational level didn't affect and strengthen the relationship between meaning and performance

H6: Education level significantly moderates the relationship between impact and performance.

The result demonstrates that the interaction between education level and impact is significant $(\beta=0.60, t=2.12, p=.035)$. Accordingly, education level significantly moderates the relationship between impact and performance. Hence, H6 is supported. This means that the education level affects and strengthens the relationship between impact and performance.

H7: Education level significantly moderates the relationship between competence and performance. 
The result shows that the educational level fails to moderate the relationship between competence and employee performance $(B=.131-$; $\mathrm{p}=.605)$. Thus, $\mathrm{H} 7$ is not supported. This means the educational level didn't affect and strengthen the relationship between competence and performance.

H8: Education level significantly moderates the relationship between self-determination and performance.

The result shows that educational level fails to moderate the relationship between self-determination on employee performance $(B=$ $.042-; \mathrm{p}=.910)$. Thus, H8 is not supported. This means the educational level didn't affect and strengthen the relationship between selfdetermination and performance.

Table 4. Using Education Level as a Moderator in the Relationship between Psychological Empowerment on Employee Performance

\begin{tabular}{|c|c|c|c|c|c|c|}
\hline \multicolumn{6}{|c|}{ Coefficients } & \multirow[b]{2}{*}{ R square } \\
\hline & & Std. Error & Beta & $\mathrm{T}$ & Sig. & \\
\hline \multirow{5}{*}{1} & (Constant) & 2.344 & & 10.06 & .020 & .512 \\
\hline & Meaning & 4.613 & .280 & 2.344 & .000 & \\
\hline & Impact & 1.766 & .116 & 4.613 & .079 & \\
\hline & Competences & $-1.070-$ & $-.063-$ & 1.766 & .286 & \\
\hline & Determination & 7.567 & .495 & $-1.070-$ & .000 & \\
\hline \multirow[b]{2}{*}{2} & (Constant) & 3.068 & & 7.567 & .002 & .529 \\
\hline & Education & -2.499 & $-.130-$ & 3.068 & .013 & \\
\hline \multirow{5}{*}{3} & (Constant) & 1.208 & & $-2.499-$ & .229 & .541 \\
\hline & MeaningXEdu & $-.938-$ & $-.427-$ & 1.208 & .350 & \\
\hline & ImpactXEdu & 2.122 & .598 & $-.938-$ & .035 & \\
\hline & CompetencesXEdu & $-.519-$ & $-.131-$ & $-.113-$ & .605 & \\
\hline & DeterminationXEdu & $-.113-$ & $-.042-$ & 2.122 & .910 & \\
\hline
\end{tabular}

\section{DISCUSSION AND CONCLUSION}

The first research objective of this study is to measure the relationship between the elements of psychological empowerment (i.e., meaning, impact, competence, self-determination) and performance of employees in four- and five-star hotels in the Dead Sea tourist destination (Sandhya and Sulphey, 2020).

The results of this study show that self-determination is the most effective factor. This result means that individuals feel that they are the decision makers at work, where they can choose the method, speed, and time to perform their jobs. This result also means that individuals will be considerably effective and professional at work, particularly in interacting with customers. The current study coincides with Tetik (2016), who concluded that meaning directly affects employee performance. This conclusion is based on the awareness of employees on the different levels of their work, the importance of their tasks and performance in achieving their goals, and the general objectives of the hotel organization. Dewettinck et al. (2003) emphasized that individuals who know the value of their work are motivated to perform well. Al-douri (2108) emphasized this importance in the results of his study on the employees of Zain Jordan Telecom. In addition, self-determination is an important predictor of performance. Degago (2104), Hameed and Waheed (2105), and Ölçer and Florescu (2015) emphasized the role of self-determination in achieving effective performance in organizations. Some studies have found no trace of self-determination in the performance of working individuals (Durrah et al., 2014; Al-douri, 2018). Moreover, the result shows that meaning has a significant impact on employee performance. This result indicates the importance of meaning and its impact at work, where employees believe that their work has value in the organization and society. This result also indicates the existing harmony between the work environment and e mployees in terms of the value of the goals and tasks based on individual criteria. This situation leads to strong communication with the work that goes beyond the formal frameworks, commitment, and responsibility for working voluntarily in the workplace. The current study confirms the results of Al-douri (2018) and Degago (2014), who believed that meaning is a key factor in psychological empowerment to achieve highlevel performance. Dewettinck et al. (2003) discussed that when individuals realize the value of their work, they will be motivated to perform tasks professionally. Tetik (2006) believed that meaning is important in predicting performance. By contrast, Durrah et al. (2004) found that meaning has no effect and is not important in performance.

The results of this study indicate that impact has no effect on the performance of hotel employees. This result means that employees do not feel the effects of the multiplicity of administrative levels and management in hotels, thereby creating a feeling that they are tools for task implementation and performance. Moreover, employees do not affect hotel strategies and management of work goals, and their behavior will not make any difference in the workplace. By contrast, Tetik (2016) and Degago (2014) found that effect is the most important element in predicting performance. Durrah et al, (2014) concluded that impact is important for effective performance. Consequently, the results of the current study indicate that competence has no effect on the performance of hotel employees. This notion means that employees lack confidence in their skills and ability to perform the tasks assigned to them. Accordingly, this situation can serve as a challenge in the internal and external work environment and unsupportive environment in the work place. By contrast, Tetik (2016) and Degago (2014) found that competence is the most important element in predicting performance. Durrah et al. (2014) also concluded that the effect is important for effective performance. Al-douri (2018) concluded that competence does not affect employee performance.

The second objective of this research is to explore whether the education level of these employees affects the relationship between psychological empowerment and their performance. Education level significantly modifies the relationship bet ween impact and employee performance. That is, education level provides individuals with wide areas of influence at work through knowledge, extensive understanding of working conditions, and the need to turn in effective performance. Individuals with high educational levels are likely to develop high functional levels within hotel organizations, thereby enabling them to influence their organizations.

The current study also indicates that education level does not significantly modify the relationship between meaning, competence, and self-determination and employee performance. That is, employees can acquire these factors at work, where they can apply their know ledge and skills to serve clients, Employees will also become considerably professional with the time factor and the acquisition of these elements by their practical experience in the hotel organization, as well as the management support, work environment, and teamwork si tuations that can improve these elements. Only a few studies have attempted to investigate the effects of educational level on the relationship between psychological empowerment and performance of hotel employees. Rashkovits and Livne (2013) found that employees with a high level of education had distinct characteristics of development, learning, and ability to work. Ambad and Bahron (2012) determined that education level does not affect the relationship between psychological empowerment and employee commitment. 
The third objective of this research is to develop a set of recommendations to enhance the psychological empowerment of hotel employees; this will positively reflect their performance, This research complements previous studies on psychological empowerment, particularly by focusing on the importance of the relationship between psychological empowerment and employee performance in the Jordanian hotel sector. Moreover, this study enriches the knowledge base of departments and researchers specializing in the performance of employees in service organizations and hotels in Jordan as following in practical implications and future research.

\section{Practical Implication}

This study believes in focusing on developing the awareness of employees to improve psychological empowerment, specifically at the administrative levels, through their influence on the work environment, as well as to consider their mistakes as opportunities to enhance work performance. Apart from adopting modern organizational structures that tend to be horizontal rather than hierarchical, recognizing employees' abilities and skills in controlling the work methods should be allowed to enhance their sense of competence and ability to develop work. Also, exchange the ideas between management and employees should also be adopted to enhance employees' sense of efficiency and influence at workplace and the hotel goals. Apart from the administration's concern for its responsibilities in maintaining the proper administrative environment (where decentralization and regulatory justice prevail).

As well as the psychological aspects of the employees in the Jordanian hotel sector, especially as the psychological situation affects the level of carrying out tasks, as well as providing opportunities for employees in hotels to express their ideas and observations, especially as they are in direct contact with customers in the workplace. In addition, create the appropriate conditions to employee in workplace which reflect in their knowledge, skills, and attitude added by the dimensions of empowerment, and refinement the performance of employees distinctly, such as Independence at work, promoting a sense of efficiency, and maximizing the sense of belonging to the hotel, and Enhance occupational safety at the workplace. A conceivable clarification for this finding is that training programs within the Korean gracious benefit is required, emphasizing moral or attitudinal issues instead of information and skillbased on-the-job preparing (Kim, 1992). We moreover accept that building competencies does not matter for employees' organizational commitment, since most open segment representatives in Korea have relatively solid work security, which makes workers smugger or maybe than motivated to construct their competencies. The necessity of recognizing the importance of delegating authority to contribute to the role of active participation, develop the character, knowledge, and skills of employees at a high level, and enhance and support their behaviors through various methods and strategies can be adopted through the following aspects: First, adopting training courses relevant skills acquisitions at work place and qualifying workers as a stage of empowerment such as customer care, functional etiquette, etiquette and protocol, communication skills, and acquiring new competences in workplaces. Second, training managers on upgrading the level of psychological empowerment, and how to create a positive work environment for workers such as courses in internal marketing, risk management, talent management, innovation management, new trends in leadership, how to be leader, and manage communication channels, thus training was characterized as systematic handle that points to assist workers upgrade their information and aptitudes, and create positive behavior through learning experience that's anticipated to assist workers accomplish more noteworthy execution. Third, motivating employees, adopting a strategy of material and moral incentives, and rewarding positive behaviors in the work environment. Fourth, enhance job security for employees which makes them more loyal and more committed to hotel, which can be reflected on their duties and performance. Finally, empowering individuals with a type of decentralization in the decision-making process at work. By giving them some powers at work, and their willingness to take responsibility to their duties and with their coll eagues.

\section{Limitations and Future Research}

The present study also has its limitations. From a methodological view point, this research only includes four- and five-star hotels in the Dead Sea tourist destination, which is a limited data pool within one region. Hence, the result may have confined the general ization to the other areas of Jordan. This study concentrates only on the room division employees in the aforementioned hotels. Evidently, concentrating on these hotels allows us to control variation across other classified and unclassified hotels. In addition, these hotels are of ten large and follow hotel chains. Thus, the impact of psychological empowerment on employee performance may not be the same with other classified and small hotels. The other limitation is this study's concentration on the hotel sector. Every tourism sector has different structures, features, and nature of delivering services, which may not be generalized to other tourism sectors. Lastly, this study used room division employee perceptions on the impact of psychological empowerment on performance instead of actual transfer performance data. An actual measurement of performance would provide a stronger measure than one based on perception. For future research, the researchers recommend further investigation into the topic. Given the current findings concerning psychology empowerment and performance, future studies should conduct an in-depth examination using different population to ascertain if the trend found in this study continues in other areas. Moreover, future research should focus on conducting longitudinal studies of empowerment to determine whether the employees have developed their performance over time. Future studies can also compare the result across times, and assist hotels in examining the result of empowerment through conducting longitudinal performance studies. Lastly, the target population of this study is room division employees in four- and fivestars hotels in the Dead Sea tourism area. Researchers should conduct additional investigation into other departments in thes e hotels, such as food and beverage, marketing and sales, human resource, engineering, and accounting departments.

\section{REFERENCES}

Abazeed, R. (2010). The effect of psychological empowerment on Citizenship Behavior of Employees in Social Security Corporation in Jordan. Journal of Alnajah University for Research, vol. 24, no. 2, http://hdl.handle.net/20.500.11888/2384.

Ahearne, M., Mathieu, J., \& Rapp, A. (2005). To empower or not to empower your sales force? An empirical examination of the influence of leadership empowerment behavior on customer satisfaction and performance. Journal of Applied psychology, 90(5), 945.

Al Najdawi, B.M., Khaleefah, Q., Shatnawi, H., \& Al Momani, E. (2017). Measuring local tourists' perceptions in Petra city as one of seven wonders of world. Journal of Environmental Management \& Tourism, 8(18), 427-435.

Al Najdawi, Bashar M. (2020). Performance Measurement System Approaches In Hotel Industry: A Comparative Study. International Journal of Scientific \& Technology Research, V. 9 - Issue 3, 3504-3507.

Al-douri, Z. (2018). The effect of psychological empowerment of employee performance in business organization. The Scientific Journal of Cihan University, vol. 2 , no. 1

Ambad, S.N.A., \& Bahron, A. (2012). Psychological empowerment: The influence on organizational commitment among employees in the construction sector. Journal of Global Business Management, 8(2), 73.

Appelbaum, S.H., Hébert, D., \& Leroux, S. (1999). Empowerment: power, culture and leadership-a strategy or fad for the millennium? Journal of Workplace Learning, 11(7), 233-254.

Aryee, S., \& Chen, Z.X. (2006). Leader-member exchange in a Chinese context: Antecedents, the mediating role of psychological empowerment and outcomes. Journal of business research, 59(7), 793-801. 
Ashforth, B.E. (1989). The experience of powerlessness in organizations. Organizational behavior and human decision processes, 43(2), 207-242.

Ashforth, B.E. (1990). The organizationally induced helplessness syndrome: A preliminary model. Canadian Journal of Administrative Sciences/Revue Canadienne des Sciences de l'Administration, 7(3), 30-36.

Baird, K., Su, S., \& Munir, R. (2018).The relationship between the enabling use of controls, employee empowerment, and performance. Personnel Review, 47(1), 257-274.

Bandura, A. (1977). Self-efficacy: toward a unifying theory of behavioral change. Psychological review, 84(2), 191.

Bandura, A. (1986). The explanatory and predictive scope of self-efficacy theory. Journal of social and clinical psychology, 4(3), 359-373.

Barbee, C., \& Bott, V. (1991).Customer treatment as a mirror of employee treatment. SAM Advanced Management Journal, $56(2), 27$.

Bartram, T., \& Casimir, G. (2007). The relationship between leadership and follower in-role performance and satisfaction with the leader: the mediating effects of empowerment and trust in the leader. Leadership \& Organization Development Journal, 28(1), 4-19.

Bedarkar, M., \& Pandita, D. (2014). A study on the drivers of employee engagement impacting employee performance. Procedia-Social and Behavioral Sciences, 133, 106-115.

Bester, J., Stander, M.W., \& Van Zyl, L.E. (2015).Leadership empowering behaviour, psychological empowerment, organisational citizenship behaviours and turnover intention in a manufacturing division. SA Journal of Industrial Psychology, 41(1), 1-14.

Bhatnagar, J. (2005). The power of psychological empowerment as an antecedent to organizational commitment in Indian managers. Human Resource Development International, 8(4), 419-433.

Bowen, D.E., \& Lawler III, E.E. (1992). The empowerment of service workers: What, why, how, and when. Sloan management review, 33(3), 31-40.

Cacioppe, R. (1998). Structured empowerment: an award-winning program at the Burswood Resort Hotel. Leadership \& Organization Development Journal, 19(5), 264-274.

Campbell, C.J., \& Wesley, C.E. (1993).Measuring security price performance using daily NASDAQ returns. Journal of Financial Economics, 33(1), 73-92.

Chang, L.C., \& Liu, C.H. (2008). Employee empowerment, innovative behavior and job productivity of public health nurses: A cross-sectional questionnaire survey. International Journal of Nursing Studies, 45(10), 1442-1448.

Chebat, J.C., \& Kollias, P. (2000). The impact of empowerment on customer contact employees' roles in service organizations. Journal of Service research, 3(1), 66-81

Chiang, C.F., \& Hsieh, T.S. (2012). The impacts of perceived organizational support and psychological empowerment on job performance: The mediating effects of organizational citizenship behavior. International journal of hospitality management, 31(1), 180-190.

Choong, Y.O., Wong, K.L., \& Lau, T.C. (2011). Psychological empowerment and organizational commitment in the Malaysian private higher education institutions: A review and research agenda. Academic Research International, 1(3), 236.

Chow, I.H.S., Lo, T.W.C., Sha, Z., \& Hong, J. (2006). The impact of developmental experience, empowerment, and organizational support on catering service staff performance. International Journal of Hospitality Management, 25(3), 478-495.

Conger, J. A., \& Kanungo, R.N. (1988). The empowerment process: Integrating theory and practice. Academy of Management Review, 13(3), 471-482..

Cunningham, I., Hyman, J., \& Baldry, C. (1996). Empowerment: the power to do what? Industrial Relations Journal, 27(2), 143-154.

Degago, E. (2014). A study on impact of psychological empowerment on employee performance in small and medium scale enterprise sectors. European Journal of Business and Management, 6(27), 60-72.

Dewettinck, K., Singh, J., \& Buyens, D. (2003). Psychological empowerment in the workplace: Reviewing the empowerment effects on critical work outcomes (pp. 1-24). Vlerick Management School, https://www.researchgate.net/publication/23646658.

Durrah, O., Khdour, N., Al-Abbadi, S., \& Saif, N. (2014). The Impact of Psychological Empowerment on the Effectiveness of Job Performance: A Field Study on the Jordanian Private Banks. European Journal of Business and Management, 6, 2222-2839.

Erstad, M. (1997).Empowerment and organizational change. International Journal of Contemporary Hospitality Management, 9(7), 325-333.

Eylon, D., \& Bamberger, P. (2000). Empowerment cognitions and empowerment acts: Recognizing the importance of gender. Group \& Organization Management, 25(4), 354-372.

Field, L. (1997). Impediments to empowerment and learning within organizations. The Learning Organization, 4(4), 149-158.

Fineman, S. (Ed.). (2009). The emotional organization: Passions and power. John Wiley \& Sons.

Fong, K.H., \& Snape, E. (2015). Empowering leadership, psychological empowerment and employee Outcomes: Testing a multi-level mediating model. British Journal of Management, 26(1), 126-138.

Geralis, M., \& Terziovski, M. (2003).A quantitative analysis of the relationship between empowerment practices and service quality outcomes. Total Quality Management \& Business Excellence, 14(1), 45-62.

Gözükara, İ., \& Şimşek, O.F. (2015).Linking transformational leadership to work engagement and the mediator effect of job autonomy: a study in a Turkish private non-profit university. Procedia-Social and Behavioral Sciences, 195, 963-971.

Hackman, J.R., \& Oldham, G.R. (1976). Motivation through the design of work: Test of a theory. Organizational Behavior and Human Performance, 16(2), $250-279$.

Hameed, A., \& Waheed, A. (2015). Impact of Psychological Empowerment on Employee's Performance. Pakistan Journal of Humanities and Social Sciences, 3(1), 1-15.

Hanaysha, J., \& Tahir, P.R. (2016).Examining the effects of employee empowerment, teamwork, and employee training on job satisfaction. Procedia-Social and Behavioral Sciences, 219, 272-282.

Hossein, R.D., Saleh, P.A., Iman, A., \& Jaafar, A. (2012). An analysis of the empowerment level of employees and it's relation to organizational factors. International Journal of Business and Social Science, 3(15), 255-263.

Hrbackova, K., \& Suchankova, E. (2016).Self-determination approach to understanding of motivation in students of helping professions. Procedia-Social and Behavioral Sciences, 217, 688-696.

Hubrecht, J., \& Teare, R. (1993).A strategy for partnership in total quality service. International Journal of Contemporary Hospitality Management, 5(3), 1-5.

Ibrahim, A.M. (2020). Psychological empowerment and organizational commitment among employees in the lodging industry. Journal of Human Resources in Hospitality \& Tourism, 1-19.

Jaradat, N, Al-maani, A., \& Hashim, J. (2013). The effect of the structural empowerment psychological empowerment at the public jordanian organizations. Journal of Hebron University for Research, vol. 8, no. 1.

Jawabreh, O., Masa'deh, R., Mahmoud, R., \& Hamasha, S.A. (2020). Factors Influencing the Employees Service Performances in Hospitality Industry Case Study Aqba Five Stars Hotel. GeoJournal of Tourism and Geosites, 29 (2), 649-661.

Johnson, B.H. (2009). EMPOWERMENTof Nurse Educators Through Organizational Culture. Nursing Education Perspectives, 30(1), 8-13.

Kara, D., Uysal, M., Sirgy, M. J., \& Lee, G. (2013). The effects of leadership style on employee well-being in hospitality. International Journal of Hospitality Management, 34, 9-18

Kassawnh, M.S., Al Makhadmeh, I.M., Shatnawi, H.S., \& Al Najdawi, B.M. (2019). The impact of behaviors and skills of tour guides in guiding tourist groups. African Journal of Hospitality, Tourism and Leisure, 8(1), 1-

Khan, J., Malik, M., \& Saleem, S. (2020). The Impact of Psychological Empowerment of Project-Oriented Employees on Project Success: A Moderated Mediation Model. Economic Research-Ekonomska Istraživanja, 33(1), 1311-1329.

Khan, M.T., Saboor, A., Khan, N.A., \& Ali, I. (2011). Connotation of employees empowerment emerging challenges. European Journal of Social Sciences, 22(4), 556-564.

Kim, P.S. (1992). Modernizing the Korean civil service: Policy alternatives for democratization. The Asian Journal of Public administration, 14 , no. 1: 63-78.

Kirkman, B.L., Rosen, B., Tesluk, P.E., \& Gibson, C.B. (2004). The impact of team empowerment on virtual team performance: The moderating role of faceto-face interaction. Academy of Management Journal, 47(2), 175-192.

Klidas, A.K. (2002). The cultural relativity of employee empowerment: Findings from the European hotel industry. In EuroCHRIE International Conference on Cross Cultural Challenges in the Tourism Industry: The Educational Answers (Vol. 31). 
Koberg, C.S., Boss, R.W., Senjem, J.C., \& Goodman, E.A. (1999). Antecedents and outcomes of empowerment: Empirical evidence from the health care industry. Group \& organization management, 24(1), 71-91.

Kundu, S.C., Kumar, S., \& Gahlawat, N. (2019). Empowering leadership and job performance: mediating role of psychological empowerment. Management Research Review, 42 (5), 605-62, https://doi.org/10.1108/MRR-04-2018-0183.

Lashley, C. (1996). Research issues for employee empowerment in hospitality organisations. International Journal of Hospitality Management, 15 (4), 333-346.

Lashley, C., \& McGoldrick, J. (1994). The limits of empowerment: A critical assessment of human resource strategy for hospitality operations. Empowerment in Organizations, 2(3), 25-38.

Lee, M., \& Koh, J. (2001). Is empowerment really a new concept? International journal of human resource management, 12(4), 684-695.

Li, Y., Wei, F., Ren, S., \& Di, Y. (2015). Locus of control, psychological empowerment and intrinsic motivation relation to performance. Journal of Managerial Psychology, 30(4), 422-438.

Liden, R.C., Wayne, S.J., \&Sparrowe, R.T. (2000). An examination of the mediating role of psychological empowerment on the relations between the job, interpersonal relationships, and work outcomes. Journal of applied psychology, 85(3), 407.

McGrath, T. (2007). An investigation into employee empowerment in four star hotels, Dublin Business School, 153 p.

Miller, K.I., \& Monge, P.R. (1986). Participation, satisfaction, and productivity: A meta-analytic review. Academy of Management Journal, $29(4), 727-753$.

Mir, R.A., \& Rainayee, R.A. (2015). Employee empowerment and its outcomes: a mediation model. Pacific Business Review International, 8(6), 1-9.

Mohammad, A.R.A.F., Al Najdawi, B.M., ElZoghbi, M., \& Abdelhadi, E.A. (2014). A Study Some Factors Affecting on Employee Turnover in The Hospitality Industry: Comparative study for Jordanian Tourist's Destinations. Journal of Association of Arab Universities for Tourism and Hospitality, 11(1), 93-102.

Ölçer, F., \& Florescu, M. (2015). Mediating effect of job satisfaction in the relationship between psychological empowerment and job performance. Theoretical and Applied Economics, 22(3), 111-136.

Onyemeh, N.C. (2017). Impact of employee psychological empowerment, process and equipment on operational service quality in the oilfield service industry (Doctoral dissertation, University of Nottingham).

Patah, M.O.R.A., Radzi, S.M., Abdullah, R., Adzmy, A., Zain, R.A., \& Derani, N. (2009). The influence of psychological empowerment on overall job satisfaction of front office receptionists. International Journal of Business and Management, 4(11), 167-176.

Pathak, D., \& Srivastava, S. (2020). Journey from passion to satisfaction: roles of belongingness and psychological empowerment. International Journal of Sociology and Social Policy.

Ponton, D.M. (2011). An analysis of Psychological Empowerment, Job Satisfaction and Organisational Commitment of Middle-level Managers in the Hospitality Industry (Doctoral dissertation, Griffith University).

Rashkovits, S., \& Livne, Y. (2013). The effect of education level on psychological empowerment and burnout - The mediating role of workplace learning behaviors. In Proceedings of World Academy of Science, Engineering and Technology (No. 78, p. 2067). World Academy of Science, Engineering and Technology (WASET).

Rothmann, S., \& Coetzer, E.P. (2003). The big five personality dimensions and job performance. SA Journal of Industrial Psychology, 29(1), 68-74.

Safari, A., Adelpanah, A., Soleimani, R., Aqagoli, P.H., Eidizadeh, R., \& Salehzadeh, R. (2020). The effect of psychological empowerment on job burnout and competitive advantage. Management Research: Journal of the Iberoamerican Academy of Management.

Saif, N.I., \& Saleh, A.S. (2013).Psychological empowerment and job satisfaction in Jordanian hospitals. International Journal of Humanities and Social Science, 3(16), 250-257.

Saleem, M.A., Bhutta, Z.M., Nauman, M., \& Zahra, S. (2019). Enhancing performance and commitment through leadership and empowerment: An emerging economy perspective. International Journal of Bank Marketing, 37(1), 303-322.

Sandhya, S., \& Sulphey, M.M. (2020). Influence of empowerment, psychological contract and employee engagement on voluntary turnover intentions. International Journal of Productivity and Performance Management.

Sarwar, A., \& Muhammad, L. (2020). Impact of employee perceptions of mistreatment on organizational performance in the hotel industry. International Journal of Contemporary Hospitality Management. DOI: 10.1108/IJCHM-01-2019-0046.

Shelton, S.T. (2002). Employees, supervisors, and empowerment in the public sector: The role of employee trust. http://www.lib.ncsu.edu/resolver/1840.16/5894.

Siachou, E., \& Gkorezis, P. (2014). Do empowered employees absorb knowledge? An empirical investigation of the effects of psychological empowerment dimensions on absorptive capacity. Management Research Review, 37(2), 130-151.

Singh, M., \& Sarkar, A. (2012). The relationship between psychological empowerment and innovative behavior. Journal of Personnel Psychology.

Spreitzer, G.M. (1995). Psychological empowerment in the workplace: Dimensions, measurement, and validation. Academy of management Journal, 38(5), 1442-1465.

Stajkovic, A.D., \& Luthans, F. (1998). Self-efficacy and work-related performance: A meta-analysis. Psychological Bulletin, $124(2), 240$.

Sun, X. (2016). Psychological Empowerment on Job Performance - Mediating Effect of Job Satisfaction. Psychology, 7(04), 584.

Tetik, N. (2016). The effects of psychological empowerment on job satisfaction and job performance of tourist guides. International Journal of Academic Research in Business and Social Sciences, 6(2), 221-239.

Thomas, K.W., \& Velthouse, B.A. (1990). Cognitive elements of empowerment: An "interpretive" model of intrinsic task motivation. Academy of management review, 15(4), 666-681.

Turnipseed, D.L., \& VandeWaa, E.A. (2020). The little engine that could: the impact of psychological empowerment on organizational citizenship behavior. International Journal of Organization Theory \& Behavior, https://doi.org/10.1108/IJOTB-06-2019-0077.

Tuuli, M.M., \& Rowlinson, S. (2009). Performance consequences of psychological empowerment. Journal of construction engineering and management, 135(12), 1334-1347.

Van Oudtshoorn, M., \& Thomas, L. (1995). A management synopsis of empowerment. Training for Quality, 3(3), $25-32$.

Wang, G., \& Lee, P.D. (2009). Psychological empowerment and job satisfaction: An analysis of interactive effects. Group \& Organization Management, 34(3), 271-296.

Yakın, M., \& Erdil, O. (2012). Relationships between self-efficacy and work engagement and the effects on job satisfaction: a survey on certified public accountants. Procedia-Social and Behavioral Sciences, 58, 370-378.

Yuk1, G.A., \& Becker, W.S. (2006). Effective empowerment in organizations. Organization Management Journal, 3(3), $210-231$.

Zhang, X., \& Bartol, K.M. (2010). Linking empowering leadership and employee creativity: The influence of psychological empowerment, intrinsic motivation, and creative process engagement. Academy of Management Journal, 53(1), 107-128.

Zhu, W., Sosik, J.J., Riggio, R.E., \& Yang, B. (2012). Relationships between transformational and active transactional leadership and followers' organizational identification: The role of psychological empowerment. Journal of Behavioral and Applied Management, $13(3), 186$.

Zimmerman, B.J. (2000). Self-efficacy: An essential motive to learn. Contemporary educational psychology, 25(1), 82-91. 